\title{
O-serogroups, virulence genes, antimicrobial susceptibility, and MLST genotypes of Shiga toxin-producing Escherichia coli from swine and cattle in Central China
}

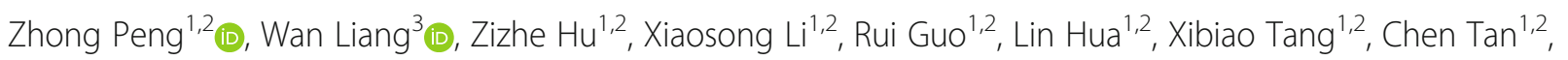
Huanchun Chen ${ }^{1,2}$, Xiangru Wang ${ }^{1,2^{*}}$ and Bin $\mathrm{Wu}^{1,2^{*}}$ (D)

\begin{abstract}
Background: Shiga toxin-producing Escherichia coli (STEC) is a leading cause of worldwide food-borne and waterborne infections. Despite an increase in the number of STEC outbreaks, there is a lack of data on prevalence of STEC at the farm level, distribution of serogroups, and virulence factors.

Results: In the present study, a total of 91 (6.16\%) STEC strains were isolated from 1477 samples including pig intestines, pig feces, cattle feces, milk, and water from dairy farms. The isolation rates of STEC strains from pig intestines, pig feces, and cattle feces were 7.41\% (32/432), 4.38\% (21/480), and 9.57\% (38/397), respectively. No STEC was isolated from the fresh milk and water samples. By O-serotyping methods, a total of 30 types of O-antigens were determined, and the main types were 0100, 097, 091, 0149, O26, 092, 0102, O157, and O34. Detection of selected virulence genes $\left(s t x_{1}\right.$, stx $x_{2}$, eae, ehxA, saa) revealed that over $94.51 \%(86 / 91)$ of the isolates carried more than two types of virulence associated genes, and approximately $71.43 \%$ (65/91) of the isolates carried both stx and $s t x_{2}$, simultaneously. Antimicrobial susceptibility tests showed that most of the STEC isolates were susceptible to ofloxacin and norfloxacin, but showed resistance to tetracycline, kanamycin, trimethoprim-sulfamethoxazole, streptomycin, amoxicillin, and ampicillin. MLST determined 13 categories of sequence types (STs), and ST297 (31.87\%; 29/91) was the most dominant clone. This clone displayed a close relationship to virulent strains STEC ST678 (O104: H4). The prevalence of ST297 clones should receive more attentions.
\end{abstract}

Conclusions: Our preliminary data revealed that a heterogeneous group of STEC is present, but the non-O157 serogroups and some ST clones such as ST297 should receive more attentions.

Keywords: Shiga toxin-producing Escherichia coli, O-serogroups, Virulence genes, Antimicrobial susceptibility, MLST genotypes

\footnotetext{
* Correspondence: wangxr228@mail.hzau.edu.cn; wub@mail.hzau.edu.cn

${ }^{1}$ State Key Laboratory of Agricultural Microbiology, College of Animal Science and Veterinary Medicine, Huazhong Agricultural University, Wuhan 430070,

China

Full list of author information is available at the end of the article
}

(c) The Author(s). 2019 Open Access This article is distributed under the terms of the Creative Commons Attribution 4.0 International License (http://creativecommons.org/licenses/by/4.0/), which permits unrestricted use, distribution, and reproduction in any medium, provided you give appropriate credit to the original author(s) and the source, provide a link to the Creative Commons license, and indicate if changes were made. The Creative Commons Public Domain Dedication waiver (http://creativecommons.org/publicdomain/zero/1.0/) applies to the data made available in this article, unless otherwise stated. 


\section{Background}

Shiga toxin-producing Escherichia coli (STEC) is a significant foodborne pathogen that is capable of causing watery or bloody diarrhea, hemorrhagic colitis, and hemolytic uremic syndrome [1-3]. O (somatic) polysaccharides and $\mathrm{H}$ (flagellar) surface antigens form the basis for the serological determination of STEC strains $[4,5]$. There are currently more than 100 types of $\mathrm{O}$ antigens having been determined from STEC isolates, and several serogroups such as O157, O26, O104, O45, O103, O111, $\mathrm{O} 121$, and $\mathrm{O} 145$ are commonly associated with severe illness in humans worldwide [2, 4, 6-9]. In China, the first ever severe outbreak of E. coli O157:H7 occurred in Xuzhou, Jiangsu Province, in 1999, which caused the death of 177 people [10]. While limited data on STEC in humans in China are available, both STEC O157 and non-O157 STEC including some predominant serogroups associated with human disease, such as O26, O45, O103, O111, and O121, have been detected and isolated from domestic and wild animals as well as raw meats in different regions [11-14]. A recent study has revealed that the overall prevalence of STEC O157:H7 was $41.3 \%$ along the production and supply chain of pork around Hubei Province in Central China, and the prevalence found in slaughter houses, wet- and supermarkets were $86.25 \%$ (69/80), 53.3\% (32/60), and $28.3 \%$ $(17 / 60)$, respectively [13]. These data suggest a big threat to the food safety and even human health in this region.

There are many virulence factors associated with the fitness and pathogenesis of STEC, but Shiga toxin (Stx, also called Vero toxin) is regarded as the most important one $[1,15]$. STEC strains mainly produce two Stx types, $\mathrm{Stx}_{1}$ and $\mathrm{Stx}_{2}$, which are further classified into three subtypes for $\operatorname{Stx}_{1}\left(\operatorname{Stx}_{1 \mathrm{a}}, \mathrm{Stx}_{1 \mathrm{c}}, \mathrm{Stx}_{1 \mathrm{~d}}\right)$ and seven subtypes for $\operatorname{Stx}_{2}\left(\operatorname{Stx}_{2 \mathrm{a}}, \mathrm{Stx}_{2 \mathrm{~b}}, \mathrm{Stx}_{2 \mathrm{c}}, \mathrm{Stx}_{2 \mathrm{~d}}, \mathrm{Stx}_{2 \mathrm{e}}, \mathrm{Stx}_{2 \mathrm{f}}, \mathrm{Stx}_{2 \mathrm{~g}}\right)$ [16]. In addition to Stx, the STEC strains also possess many other virulence determinants, including the locus of enterocyte effacement (LEE), hemolysin, STEC autoagglutinating adhesion (Saa), lipopolysaccharide (LPS), outer membrane proteins (OMPs), fimbrial, and peroxidase $[15,17-22]$.

It is proposed that food-producing animals such as cattle, pigs, chickens are major reservoirs for STEC [23]; and many STEC outbreaks are associated with consumption of meat and other products of food-producing animals contaminated with STEC strains, and/or water contaminated with feces of food-producing animals [24, 25]. Despite an increase in the number of STEC outbreaks, there is a lack of data on prevalence of STEC at the farm level, distribution of serogroups, and virulence factors [2]. Since pork and milk are the common daily food for the Chinese people and Central China, including Hubei, Anhui, Hunan and Henan provinces, is one of main pig rearing and pork producing regions in
China, in this study, we performed an isolation, identification and characterization of STEC strains from pigs, cattle, milk and water samples collected from pig and cattle farms in Central China.

\section{Results}

Isolation of STEC

A total of 1477 samples, including 432 samples of intestinal contents from pigs with diarrhea, 480 fecal samples from pigs with diarrhea, 397 fecal samples from cows with diarrhea, 99 samples of fresh milk and 69 water samples from dairy farms, were collected from four provinces of Central China (Hubei, Anhui, Hunan, Henan) for PCR detection of Shiga toxin encoding genes $(s t x)$ and STEC isolation. Of the 1477 samples detected, 119 (8.06\%) samples were positive for $s t x_{1}$ and/or $s t x_{2}$. STEC strains were isolated from 91 (76.47\%) of the 119 stx-positive samples. The isolation rates of STEC strains from pig intestines, pig feces, and cattle feces were 7.41\% (32/432), 4.38\% (21/480), and 9.57\% (38/397), respectively (Fig. 1a, Table 1). However, there were no STEC strains being isolated from the fresh milk and water samples collected (Fig. 1a, Table 1). Biochemical tests showed that all isolates were capable of fermenting glucose, maltose, lactose, and xylose, raffinose, lysine, and ornithine, but were unable to use gluconate, phenylalanine, and citrate.

\section{Serogroups and virulence genotypes}

By O-serotyping methods, a total of 30 categories of serogroups were determined for the 93 STEC isolates, and O100, O97, O91, O149, O26, O92, O102, O157, and O34 were the main serogroups (Fig. 2). There were 17 categories of serogroups identified among the bovine isolates (isolates from cow-associated samples), and 25 categories of serogroups among the porcine isolates (isolates from pig-associated samples) (Fig. 2, Table 1). Main serogroups among the porcine isolates were O100, O97, O149, O102, and O34. For bovine isolates, prevalent serogroups were O91, O97, O100, O157, and O26 (Fig. 2). In particularly, serogroup $\mathrm{O} 157$ was only detected in STEC strains originated from cows.

The positive rate of the four virulence associated genes $\left(s t x_{1}, s t x_{2}\right.$, eae, ehxA, saa) among the 91 STEC isolates ranged from $6.59 \%(e a e, 6 / 91)$ to $89.01 \%$ (stx2, 81/91) (Fig. 3a). The detection rates of the two Stx encoding genes $s t x_{1}$ and $s t x_{2}$ were $82.42 \%(75 / 91)$ and $89.01 \%(81 /$ 91), respectively. Among the $s t x_{1}$-positive isolates, $s t x_{1 a}$ was the most predominant subtype $(78.67 \%, 59 / 75)$, followed by $s t x_{1 \mathrm{c}}(17.33 \%, 13 / 75)$ and $s t x_{1 \mathrm{~d}}(4.00 \%, 3 / 75)$. For the $s t x_{2}$-positive isolates, $s t x_{2 \mathrm{e}}$ was the most predominant subtype $(56.79 \%, 46 / 81)$, followed by $s t x_{2 b}(17.28 \%$, $14 / 81)$, stx 2d $(9.88 \%, 8 / 81)$, stx $_{2 \mathrm{a}}(7.14 \%, 6 / 81)$, stx $_{2 \mathrm{c}}$ $(6.17 \%, 5 / 81)$ and stx $_{2 \mathrm{~g}}(2.47 \%, 2 / 81)$. Stx $_{1 \mathrm{a}}(100 \%, 33 / 33)$ 


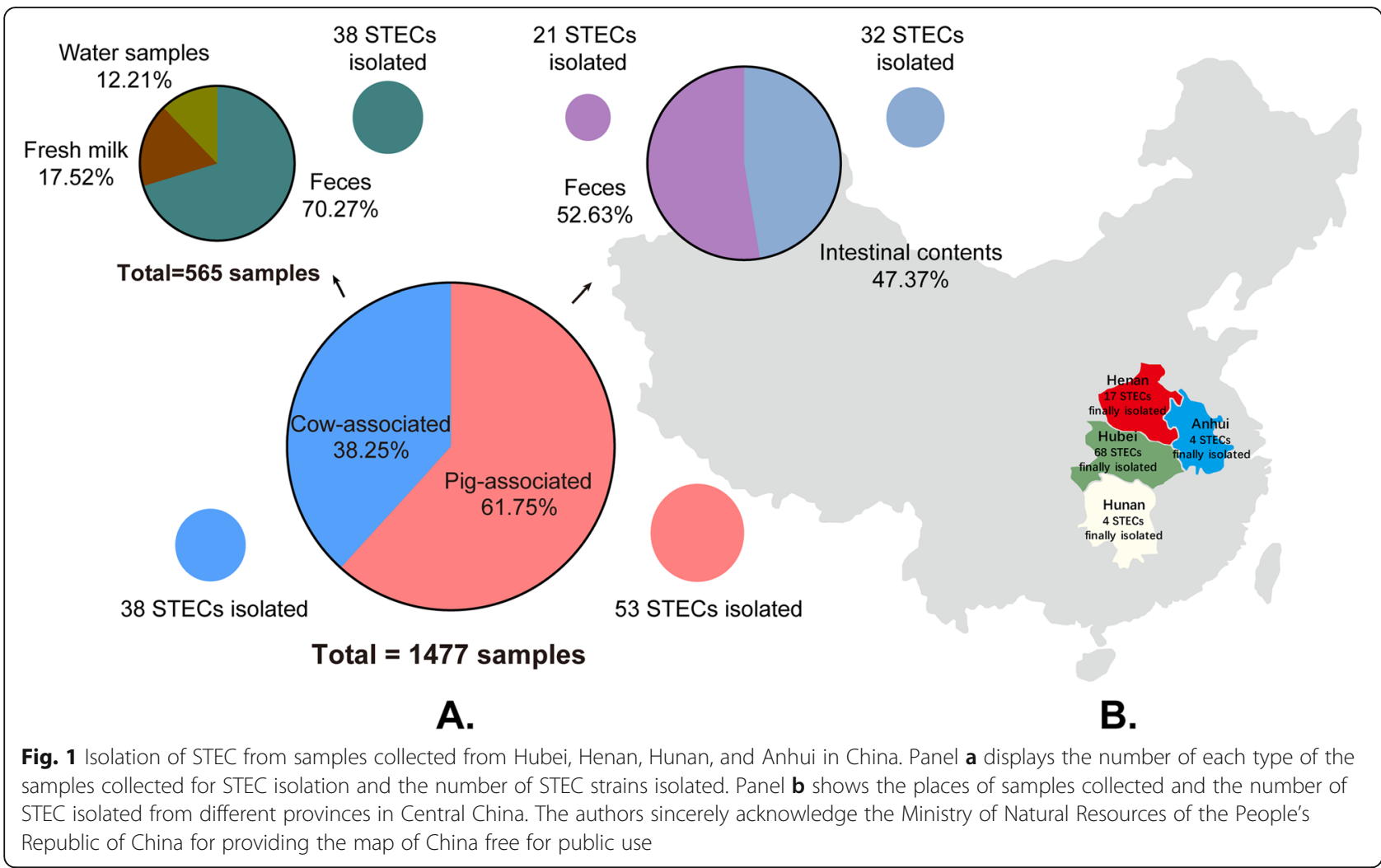

and $\operatorname{stx}_{2 \mathrm{~b}}(46.67 \%, 14 / 30)$ were the most predominant $s t x_{1}$ and $s t x_{2}$ subtypes for the bovine isolates while stx $_{1 \mathrm{a}}(61.90 \%, 26 / 42)$ and $s t x_{2 \mathrm{e}}(91.20 \%, 46 / 51)$ were the most predominant stx $x_{1}$ and $s t x_{2}$ subtypes for the porcine isolates. Over $94.51 \%(86 / 91)$ of the isolates carried more than two types of virulence associated genes, and approximately $71.43 \%(65 / 91)$ of the isolates carried both $s t x_{1}$ and $s t x_{2}$, simultaneously (Fig. $3 b)$. The percentages of the isolates carrying four types, three types, two types, and one type of the virulence genes detected were $18.68 \%$ (17/91), 58.24\% $(53 / 91), 17.58 \%(16 / 91)$, and $5.49 \%$ (5/91), respectively. Approximately $10.99 \%$ (10/91) of the isolates only carried $s t x_{1}$, and $17.58 \%(16 / 91)$ of the isolates only carried $s t x_{2}$.

In combination the serogroups with the virulence genes, isolates with different serogroups except O157 carried at least one Stx encoding gene (Table 1). In addition, all O100, O149, O26, O34, O91, and O97 isolates (the number of isolates with these serogroups is more than three) were negative to eae, while all $\mathrm{O} 102$, O149, O157, O26, and O34 isolates were PCR-negative for the presence of saa (Table 1).

\section{Cytotoxicity}

Cytotoxicity tests showed that all isolates positive to $s t x_{1}$ and/or $s t x_{2}$ were capable of making Vero cells rounding and exfoliation. However, no cytopathic effect was observed in the cells inoculated with the isolates negative to both $s t x_{1}$ and $s t x_{2}$.

\section{Antimicrobial susceptibility}

Antimicrobial susceptibility testing results showed that more than $50 \%$ of the STEC isolates were sensitive to ofloxacin (71.43\%; 65/91), and norfloxacin (61.54\%; 56/91). However, less than $10 \%$ of the isolates were sensitive to amoxicillin (7.69\%; 7/91), ampicillin (4.40\% 4/91), and kanamycin (4.40\% 4/91). In particularly, all isolates were resistant to erythromycin $(100 \%, 91 / 91)$ (Fig. 4). Most of the isolates from cattle feces were sensitive to norfloxacin $(97.37 \%$; 37/38), trimethoprim-sulfamethoxazole $(84.21 \%, 32 / 38)$, and streptomycin (76.32\%; 29/38). All isolates tested herein were sensitive to colistin; the MIC values were determined as $\leq 1 \mu \mathrm{g} / \mathrm{ml}$. Approximately half of the bovine isolates were sensitive to sulfafurazole $(55.26 \%$; $21 / 38$ ) and ofloxacin (47.37\%; 18/38). For isolates from pigs, $88.68 \%(47 / 53)$ of the isolates were sensitive to ofloxacin. However, there were no isolates from pig intestines and/or feces sensitive to trimethoprim-sulfamethoxazole, streptomycin, sulfafurazole, neomycin, gentamicin, tetracycline, amoxicillin, ampicillin, kanamycin, and cefotaxime (Fig. 4). 
Table 1 Serogroups, virulence factors and sequence types (STs) of the 91 STEC isolates

\begin{tabular}{|c|c|c|c|c|c|c|c|c|c|c|c|c|c|c|c|}
\hline ST & No. of isolates & Serogroup & $S t x_{1}$ & Stx $x_{2}$ & eae & ehxA & $\overline{s a a}$ & ST & No. of isolates & Serogroup & Stx & $S t x_{2}$ & eae & $e h x A$ & saa \\
\hline \multirow[t]{5}{*}{ ST10 } & 5 & $\mathrm{O} 34$ & + & + & - & + & - & & & O97 & + & + & - & + & - \\
\hline & & O92 & - & + & - & - & - & & & O97 & + & + & - & + & - \\
\hline & & O97 & - & + & - & + & - & & & O97 & + & + & - & + & - \\
\hline & & 098 & + & + & - & - & + & & & O97 & + & + & - & + & - \\
\hline & & 0149 & - & + & - & + & - & & & 0100 & + & + & - & + & - \\
\hline \multirow[t]{2}{*}{ ST26 } & 2 & O69 & + & + & - & + & + & & & 0100 & + & - & - & + & + \\
\hline & & 0100 & - & + & - & + & + & & & 0100 & + & - & - & + & - \\
\hline \multirow[t]{11}{*}{ ST29 } & 11 & 076 & + & + & - & + & + & & & 0100 & + & - & - & + & - \\
\hline & & O92 & + & + & + & - & - & & & 0145 & + & + & - & + & - \\
\hline & & O97 & + & + & - & + & - & & & 0149 & - & + & - & + & - \\
\hline & & O97 & + & + & - & + & - & & & 0173 & + & + & - & + & - \\
\hline & & 0100 & + & + & - & + & + & & & 0173 & + & + & - & + & - \\
\hline & & 0100 & + & - & - & + & + & ST542 & 2 & 0157 & + & + & + & + & - \\
\hline & & 0100 & + & + & - & + & - & & & 0157 & + & + & + & + & - \\
\hline & & 0102 & - & + & + & - & - & ST602 & 13 & $\mathrm{O} 34$ & + & + & - & + & - \\
\hline & & 0102 & - & + & + & - & - & & & O34 & + & + & - & + & - \\
\hline & & 0102 & + & + & - & + & - & & & O55 & + & + & - & + & - \\
\hline & & Nontypable & + & + & - & + & - & & & $\mathrm{O} 75$ & + & + & - & + & - \\
\hline \multirow[t]{7}{*}{ ST101 } & 7 & $\mathrm{O} 26$ & + & + & - & - & - & & & O91 & + & - & - & + & + \\
\hline & & O97 & + & + & - & + & - & & & O91 & + & - & - & + & - \\
\hline & & 0100 & - & + & - & - & - & & & O91 & + & - & - & + & - \\
\hline & & 0100 & + & + & - & + & + & & & O91 & + & - & - & + & - \\
\hline & & 0100 & + & + & - & + & - & & & O91 & + & - & - & + & + \\
\hline & & 0102 & + & + & - & + & - & & & O97 & + & + & - & + & - \\
\hline & & 0149 & - & + & - & + & - & & & 0118 & + & + & - & + & + \\
\hline ST156 & 1 & O64 & + & + & - & + & - & & & 0149 & + & + & - & + & - \\
\hline \multirow[t]{17}{*}{ ST297 } & 29 & O5 & + & + & - & + & - & & & Nontypable & + & + & - & + & - \\
\hline & & O6 & + & + & - & + & - & ST793 & 1 & $\mathrm{O} 3$ & - & + & + & - & - \\
\hline & & $\mathrm{O} 21$ & - & + & - & + & - & ST813 & 4 & $\mathrm{O} 34$ & + & + & - & - & - \\
\hline & & $\mathrm{O} 22$ & + & + & - & + & + & & & O92 & + & + & - & + & - \\
\hline & & $\mathrm{O} 26$ & + & + & - & + & - & & & O97 & + & + & - & + & - \\
\hline & & O26 & + & + & - & + & - & & & 0100 & + & + & - & + & - \\
\hline & & $\mathrm{O} 26$ & + & + & - & + & - & ST1294 & 8 & O91 & + & - & - & + & + \\
\hline & & $\mathrm{O} 26$ & + & + & - & + & - & & & 0100 & + & + & - & + & + \\
\hline & & O39 & - & + & - & + & - & & & 0110 & + & + & - & + & + \\
\hline & & O54 & + & + & - & + & - & & & 0149 & + & + & - & + & - \\
\hline & & O55 & + & + & - & + & - & & & Nontypable & + & + & - & + & - \\
\hline & & $\mathrm{O} 75$ & + & + & - & + & - & & & Nontypable & + & + & - & + & - \\
\hline & & O91 & + & + & - & + & - & & & Autoagglutination & - & + & - & - & - \\
\hline & & O91 & + & + & - & + & + & & & Autoagglutination & - & + & - & - & - \\
\hline & & O97 & + & + & - & + & - & ST1623 & 6 & O42 & + & + & - & + & - \\
\hline & & O97 & + & + & - & + & + & & & O54 & + & + & - & + & - \\
\hline & & O97 & + & + & - & + & + & & & O78 & - & + & - & + & + \\
\hline
\end{tabular}

Table 1 Serogroups, virulence factors and sequence types (STs) (Continued) 
Table 1 Serogroups, virulence factors and sequence types (STs) of the 91 STEC isolates (Continued)

\begin{tabular}{|c|c|c|c|c|c|c|c|}
\hline ST & No. of isolates & Serogroup & $S t x_{1}$ & $S t x_{2}$ & eae & ehxA & saa \\
\hline & & O92 & + & + & - & + & + \\
\hline & & 092 & + & + & - & + & + \\
\hline & & 0149 & - & + & - & - & - \\
\hline \multirow[t]{2}{*}{ ST1721 } & 2 & O9 & + & + & - & + & + \\
\hline & & 0167 & + & + & - & + & + \\
\hline
\end{tabular}

"+": Positive; "-": Negative

\section{MLST genotypes}

A total of 13 categories of sequence types (STs) were determined among the 91 STEC isolates using the MLST method (Fig. 5). Among these STs, ST297 (31.87\%; 29/ 91) was the most frequent, followed by ST602 (14.29\%; 13/91). The other determined STs included ST29 (12.09\%; 11/91), ST1294 (8.79\%; 8/91), ST101 (7.69\%; 7/ 91), ST1623 (6.59\%; 6/91), ST10 (5.49\%; 5/91), ST813 (4.39\%; 4/91), ST542 (2.20\%; 2/91), ST1721 (2.20\%; 2/ 91), ST26 (2.20\%; 2/91), ST156 (1.10\%; 1/91), and ST793 $(1.10 \% ; 1 / 91)$. For the 53 porcine isolates, a total of 11 types of STs were determined, and ST29 (20.75\%; 11/ 53), ST602 (15.09\%; 8/53), ST101 (13.21\%; 7/53), ST297 (11.32\%; 6/53), and ST1294 (11.32\%; 6/53) were the common STs (Fig. 5). For the 38 bovine isolates, seven types of STs were identified, and ST297 (60.53\%; 23/38), ST602 (13.16\%; 5/38), ST542 (5.26\%; 2/38), and ST1623 (10.53\%; 4/38) were commonly present (Fig. 5).

Phylogenetic analysis showed that the MLST genotypes ST297, ST602, ST101, and ST26 displayed a relationship, and they also showed a close relatedness to the epidemic MLST genotypes ST678 (O104: H4) and ST17 (O45: H2) (Fig. 6). In addition, genotype ST29 was closely related to ST16 (O111: H8), ST21 (O26: H11; O145: $\mathrm{H}+$ ), and ST723 (O103: H11) (Fig. 6).

\section{Discussion}

STEC is a leading cause of foodborne and waterborne infections worldwide, food-producing animals such as cattle, and pigs are major reservoirs for STEC [23]. Among different kinds of food producing animals, cattle and other ruminants are considered to be the major reservoirs for STEC [23, 27, 28]. STEC strains are more frequently isolated from cattle and other ruminants than from other animals such as pigs, cats, and dogs [23, 29]. In agreement with these suggestions, the rate of STEC isolation from cattle $(9.57 \%)$ was higher than that from pigs $(5.81 \%)$. However, the isolate rate of STEC from cattle feces $(9.57 \%)$ in present study is different from the reports from the other countries [2, 29]. These differences might be explained by differences in feed, seasonal peak, age, or detecting methods [2].

A total of 30 types of $\mathrm{O}$-antigen were determined for the 91 STEC isolates by O-serotyping methods, with the exception of 4 isolates which were not typable (Fig. 2). This might be because there are only 50 types of $\mathrm{O}$ antisera are available, and these four strains do not react with the available antisera. Among these 30 categories of O-serogroups, the most frequently occurring serogroups were O100, O97, O91, O149, O26, O92, O102, O157, and O34 (Fig. 2). These serogroups have been isolated from pigs, cattle, sheep, and water in both China and the other countries [30-37]. It has been known that O157 is the most common serogroup that causes human illness in most parts of the world [4]. It has been also reported that cattle are the most common reservoir of $E$. coli O157 [38]. Corresponding to this suggestion, the O157 serogroup was only determined within the isolates from cattle in the present study (Fig. 2). Although there was no STEC O157 being isolated from pigs in Central China in the present study, a recent study has revealed that the overall prevalence of $E$. coli O157:H7 in pig

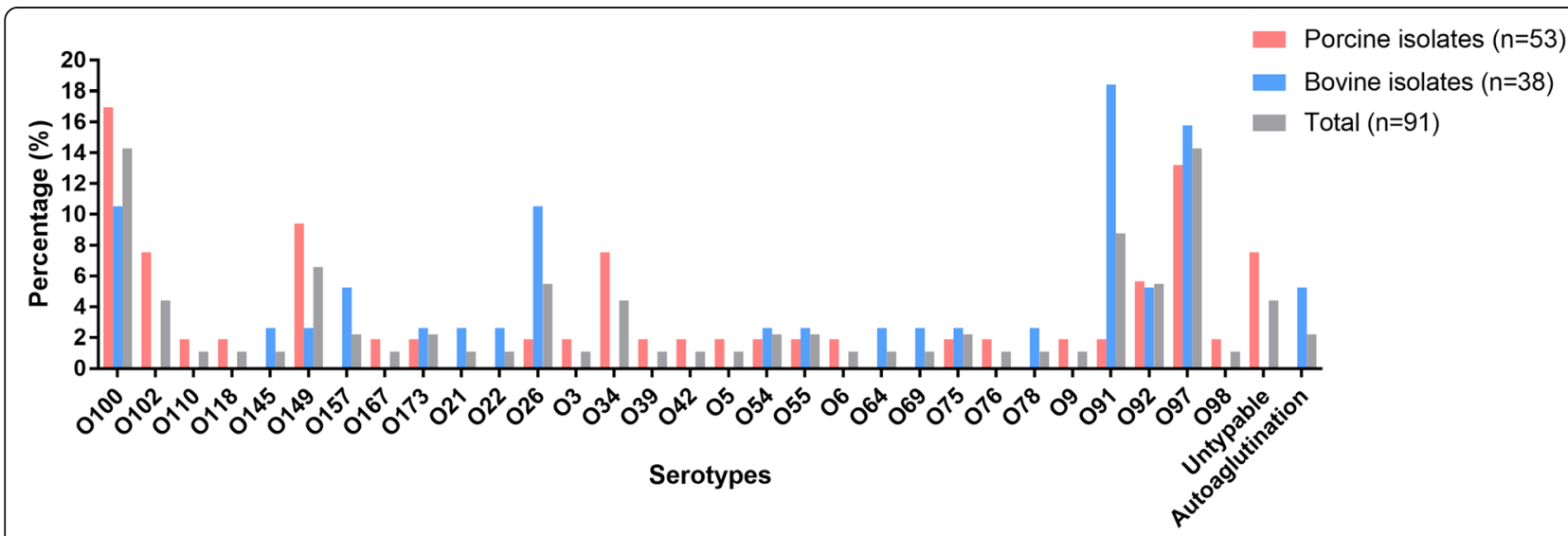

Fig. 2 Distribution of the O-antigens among the STEC isolates. Columns in pink displays the percentage of STECs isolated from the feces and intestinal contents of pigs; Columns in sky blue displays the percentage of STECs isolated from the feces of cows; Columns in gray displays the percentage of the total STECs isolated herein (STECs from pigs plus STECs from cows) 


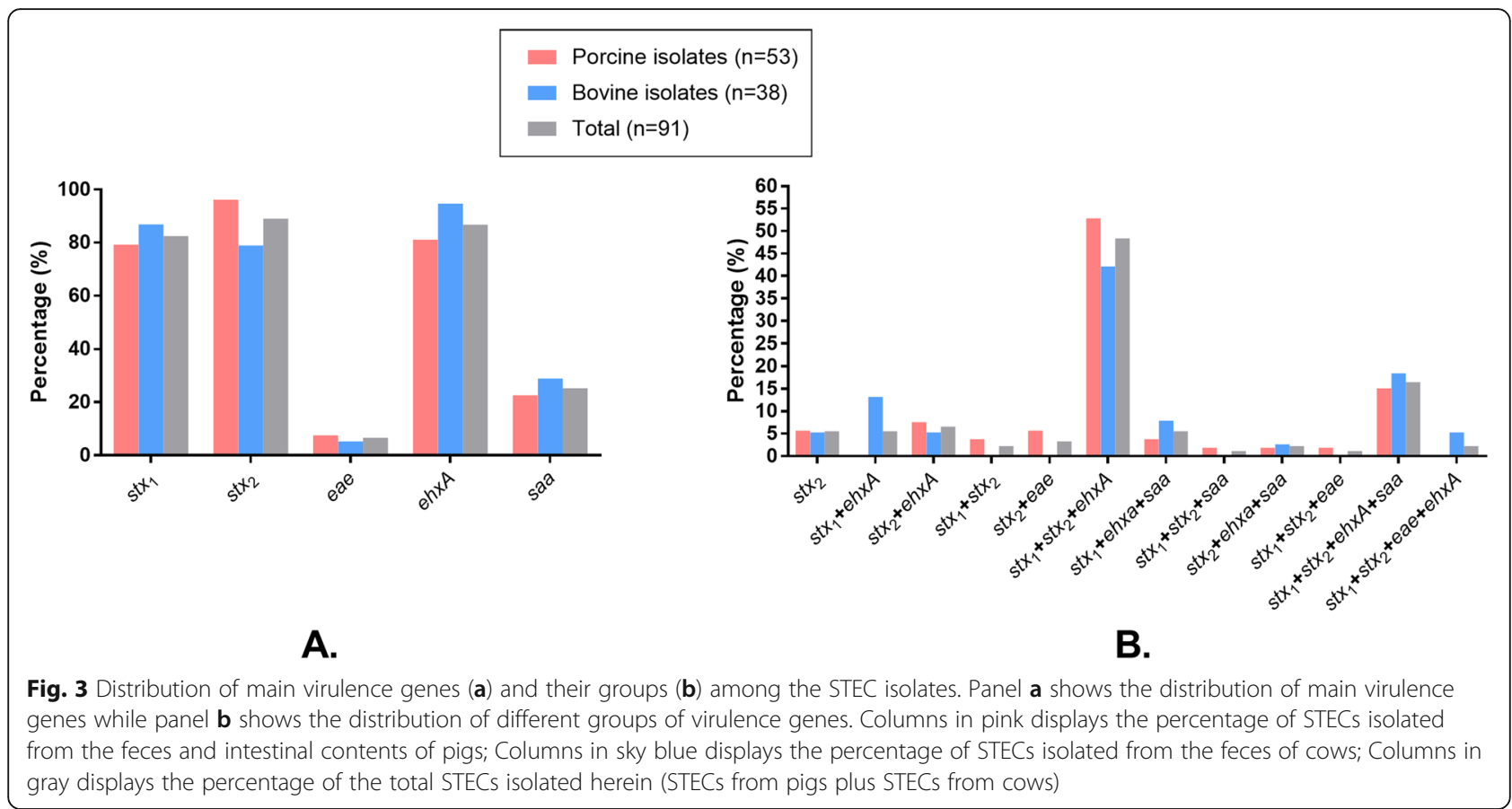

farms around Hubei, a province located in Central China, is approximately $12.8 \%(16 / 125)$ [13]. These findings suggest that the prevalence of E. coli $\mathrm{O} 157$ in this region is still a problem. In addition to O157, O26 also displayed a high proportion of identification (Fig. 2). It is worthy of note that this type of $\mathrm{O}$-antigen has been declared by the U.S. Department of Agriculture (USDA) as one of the "Big 6" (O26, O45, O103, O111, O121, and O145) non-O157 serogroups that are most commonly associated with severe illness in humans [4]. STEC O26 has been detected and isolated from diarrheal patient in China [11]. It should be noted that another member of the "Big 6", the O145, was also identified in the present study (Fig. 2). In addition, STEC O149 has been also detected and isolated from diarrheal patient in China [11]. The determination of these non-O157 serogroups represents a great risk on public health and should also receive more attentions.

Virulence genotyping based on the detection of six virulence genes $\left(s t x_{1}, s t x_{2}, e h x A\right.$, eae, and $\left.s a a\right)$ showed that the detection rates of $s t x_{1}(82.42 \%), s t x_{2}$ (89.01\%), and $e h x A(86.81 \%)$ were higher than those of the other virulence genes (Fig. 3a); most of the STEC isolates possess $s t x_{1}, s t x_{2}$, and $e h x A$ simultaneously (Fig. 3b). It is known that both $s t x_{1}$ and $s t x_{2}$ are responsible for encoding the Shiga toxin, which is the most important and

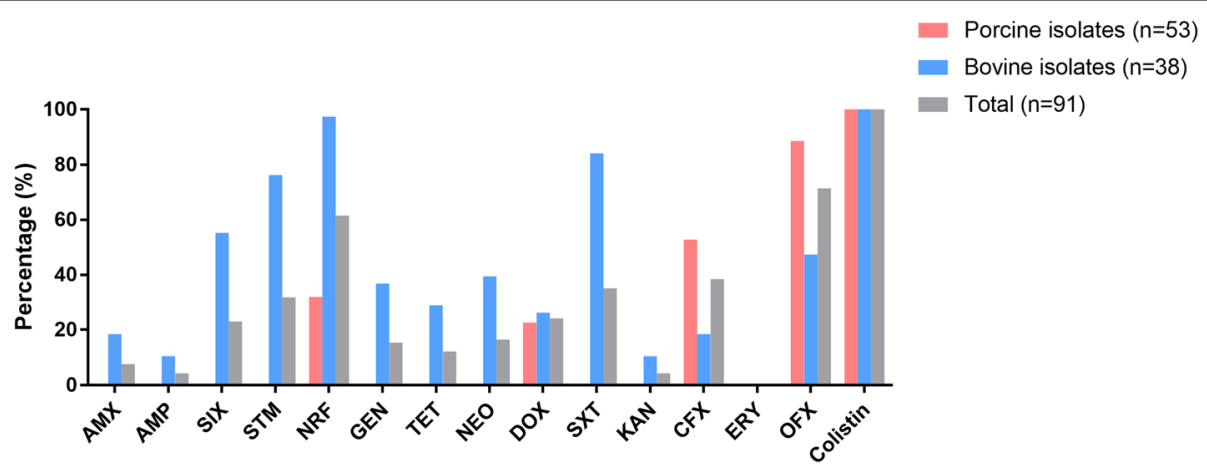

Fig. 4 Antimicrobial susceptibility of the 91 STEC isolates. AMX: amoxicillin; AMP: ampicillin; SIX: sulfafurazole; STM: streptomycin; NRF: norfloxacin; GEN: gentamicin; TET: tetracycline; NEO: neomycin; DOX: doxycycline; SXT: trimethoprim-sulfamethoxazole; KAN: kanamycin; CFX: cefotaxime; ERY: erythromycin; OFX: ofloxacin. Columns in pink displays the percentage of STECs isolated from the feces and intestinal contents of pigs; Columns in sky blue displays the percentage of STECs isolated from the feces of cows; Columns in gray displays the percentage of the total STECs isolated herein (STECs from pigs plus STECs from cows) 


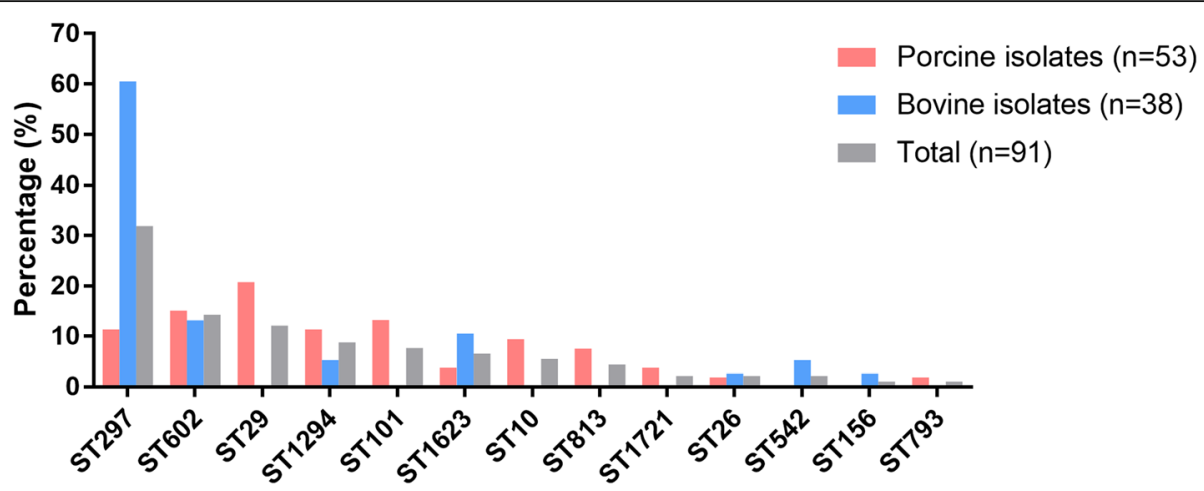

Fig. 5 Distribution of the sequence types (STs) among the STEC isolates. Columns in pink displays the percentage of STECs isolated from the feces and intestinal contents of pigs; Columns in sky blue displays the percentage of STECs isolated from the feces of cows; Columns in gray displays the percentage of the total STECs isolated herein (STECs from pigs plus STECs from cows)

common virulence factors of STEC [15]. In particular, the detection rate of $s t x_{2}(89.01 \%)$ was higher than $s t x_{1}$ (82.42\%), and a small proportion of isolates $(5.49 \%, 5 /$ 91) only carried $s t x_{2}$ (Fig. 3a and b). It has been reported that $s t x_{2}$ is more often associated with severe disease [39]. Therefore, those strains might be more harmful. Both $\mathrm{Stx}_{1}$ and $\mathrm{Stx}_{2}$ have several subtypes, and some subtypes are more frequently associated with human disease [4]. It has been widely documented that STEC isolates from pigs normally harbor $S_{2} x_{2 e}$ subtype [40-42], and in agreement with these studies [40-42], approximately $91.20 \%$ of the porcine isolates positive to $s t x_{2}$ determined in the present study harbored this subtype $\left(\operatorname{Stx}_{2 \mathrm{e}}\right)$.
STEC producing Stx2e is known to be closely associated with edema disease in pigs [43], the high proportion of $s t x_{2 \mathrm{e}}$ detection in STEC isolates from pig intestines and/ or feces in this study suggest a big threat to the pig health. Although $\mathrm{Stx}_{2 \mathrm{e}}$-producing STEC strains are still not proposed as pathogens for humans [43], active actions are still required to control and decrease the prevalence of such strains in pigs in a One Health perspective. In the present study, we also identified several other Stxsubtypes such as $\operatorname{Stx}_{1 \mathrm{a}}, \mathrm{Stx}_{1 \mathrm{c}}, \mathrm{Stx}_{1 \mathrm{~d}}, \mathrm{Stx}_{2 \mathrm{~b}}, \mathrm{Stx}_{2 \mathrm{~d}}, \mathrm{Stx}_{2 \mathrm{a}}$, $\mathrm{Stx}_{2 \mathrm{c}}$, and $\mathrm{Stx}_{2 \mathrm{~g}}$. Among these subtypes, stx $\mathrm{x}_{2 \mathrm{a}}$ and $s t x_{2 \mathrm{c}}$ are proposed to be associated with high virulence and the ability to cause hemolytic-uremic syndrome (HUS),

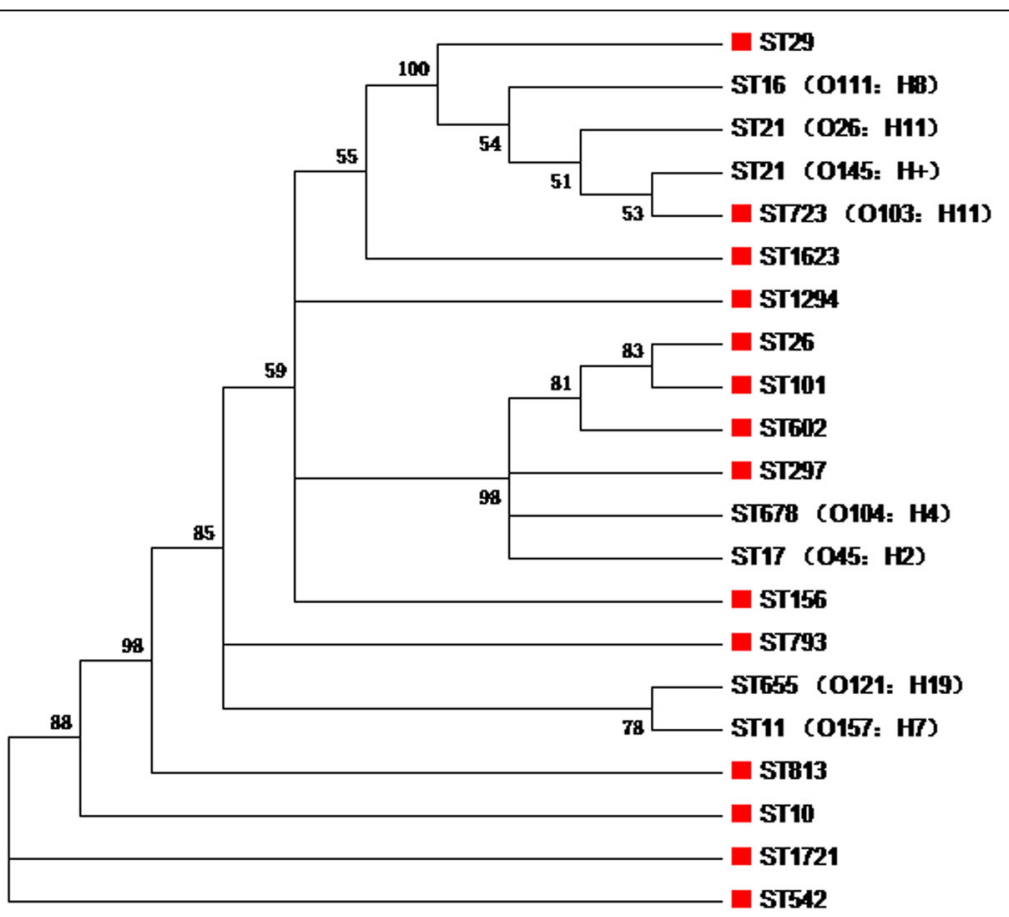

Fig. 6 Phylogenetic analysis on different STEC sequence types clones. The tree was constructed based on the MLST data by MEGAX [26], using neighbor-joining algorithm with 1000 bootstrapping 
while $s t x_{2 \mathrm{~d}}, s t x_{2 \mathrm{e}}, s t x_{1 \mathrm{a}}$, and $s t x_{1 \mathrm{c}}$ occurred in milder or asymptomatic infections [43, 44]. The detection of those subtypes in STEC strains from food producing animals such as pigs and cows we detected in this study represents a high risk on public health. It is worthy of note that $s t x_{1 \mathrm{~d}}, s t x_{2 \mathrm{~b}}, s t x_{2 \mathrm{~g}}$ have been also detected in STEC strains from patients in Demark, however, HUS does not develop in these patients [45-47].

In addition to $s t x_{1}$ and $s t x_{2}$, the prevalence of $e h x A$ (86.81\%) was also very high, showing a good agreement with previously studies [48-51]. It is worthy of note that $e h x A$ is generally used as a diagnostic indicator because the presence of $e h x A$ is frequently correlated with the Shiga toxin $[49,51]$. In agreement with this conclusion, $e h x A$ displayed a high detection rate from the stx-positive STEC strains in the present study (Fig. 3b). In contrast to these genes which have high rates of detection, the detection rates of eae, and saa were relatively low. These results are similar to previously studies [50, 51], suggesting that these virulence genes are not common. However, their presence in particularly the detection of eae should be given a concern. It has been reported that the combination of eae and $s t x_{2}$ has an especial association with the development of HUS and bloody diarrhea $[46,47,52]$. In the present study, all eae-positive STEC strains isolated in Central China were detected to be positive for $s t x_{2}$ (Table 1). The determination of such strains represents a high risk on public health in this region.

The antimicrobial resistance (AMR) of STEC is also a serious problem that the world is now facing. It has been reported that STEC isolates from both humans and foodproducing animals displayed resistance most often to tetracycline, kanamycin, trimethoprim-sulfamethoxazole, streptomycin, amoxicillin, and ampicillin [36, 53-56]. In agreement with these studies, a low proportion of STEC isolates from the present study was susceptible to those types of antimicrobials (Fig. 4). These findings suggest a serious profile of AMR in STEC in food-producing animals. While there is a number of articles reporting the colistin resistance prevalence in E. coli [57-59], it is worthy of note that all STEC isolates were sensitive to colistin in the present study.

MLST is also a strategy commonly used for STEC surveillance $[36,60]$. In this study, 13 types of STs were determined for the 91 STEC isolates. In particularly, many isolates belonging to different STs possessed the same serogroups (Table 1). These findings are consistent with the findings of other publications [61, 62], suggesting that STEC isolates with the same serogroups might have genotypical diversity. Among the determined STs, ST297 possesses the highest rate of isolation (31.87\%) compared to the remaining identified STs (Fig. 5). Interestingly, ST297 is rarely reported in STEC. A previous study determined five ST297 from 75 STEC food strains, with a detection rate of $6.67 \%$ [63]. In another study, the detection rate of ST297 among STEC isolates from cattle in Korea was only 4.69\% (3/64) [64]. Our results are quite different from these studies, suggesting that the prevalence of the ST in different regions of the world might be different. The ST297 isolates harbored many types of O-antigens, including $\mathrm{O} 26$ and $\mathrm{O} 145$, the important members of the "Big 6" declared by the USDA [4]. In particular, all $\mathrm{O} 26$ isolates recovered in the present study are ST297 clone (Table 1). It has been reported that the STs of STEC O26 associated with a broad spectrum of diseases in Europe are ST29 and/or ST21 [65-70]. In addition, the ST297 clones isolated in this study displayed a close relationship to STEC ST678 (O104: H4) (Fig. 6). It should be noted that the STEC ST678 (O104: H4) isolates have caused the outbreak of human gastroenteritis and human hemolytic-uremic syndrome in Europe $[8,71]$. In the next step, we intend to do follow up study to determine the genetic and phenotypical characteristics of these ST297 clones. In addition, the sequence types of the two STEC O157 were determined as ST542 (Table 1). Although the sequence type of STEC O157 is normally determined as ST11 [61, 72], O157 isolates determined as non-ST11 have been also documented elsewhere. For instance, four O157 isolates from the US and/or UK are determined as ST1804 [62]. These findings suggest there might be other STs for STEC O157. In the next step, we will do follow up study to determine the genetic and phenotypical characteristics of these two isolates.

\section{Conclusions}

In conclusion, the present study performed an isolation and a characteristic analysis of STEC from pigs and cattle. Our preliminary data revealed that a heterogeneous group of STEC is present, but the non-O157 serogroups and some ST clones such as ST297 should receive more attentions. In the next step, we intend to do a follow up study to correlate the pathogenicity of these STEC with the $s t x$-subtypes as well as the ST clones.

\section{Methods}

Sample collection and bacterial isolation

A total of 1477 samples were tested in this study. These samples included intestinal contents from pigs with diarrhea (432 samples), fecal samples from pigs (480 samples) and cows (397 samples) with diarrhea, fresh milk (99 samples), and water samples from dairy farms (69 samples) (Fig. 1a). The 912 pig-associated samples (feces and intestinal contents) were collected from 323 pig farms in Central China (Hubei, Anhui, Hunan, Henan) between 2016 and 2017, while the 565 cow-associated samples (feces, milk, and water samples from dairy 
farms) were from three dairy farms in different regions Hubei Province in 2017 (Fig. 1a and b). Bacterial isolation was performed following a previously described protocol with some modifications [2]. In brief, each of the samples were mixed in sterilized $0.9 \%$ normal saline by vortexing. After a centrifugation at $500 \times g$ for $1 \mathrm{~min}$, $500 \mu \mathrm{L}$ of the supernatant of the mixture was inoculated into $5 \mathrm{~mL}$ modified $E$. coli broth (Nissui, Tokyo, Japan) and incubated at $37^{\circ} \mathrm{C}$ for $18 \sim 24 \mathrm{~h}$.

After that, genomic DNA was extracted from the cultures by boiling $100 \mu \mathrm{L}$ aliquot of each incubated broth directly, as described previously [2]. The extracted DNA was evaluated by electrophoresis on a $1 \%$ agarose gel and/or using a Nanodrop2000 (Thermo Scientific, Waltham, USA). Presence of the Stx encoding gene $s t x_{1}$ and/ or $s t x_{2}$ was determined by PCR assays using the genomic DNA extracted herein as the template and the primers listed in Table 2. PCR reaction was performed in a $25 \mu \mathrm{L}$ mixture containing $2 \mu \mathrm{L}$ of the template DNA, $2.5 \mu \mathrm{L}$ of 10× PCR Buffer (TAKARA, Japan), $2 \mu \mathrm{L}$ of dNTP (TAKARA, Japan), $0.5 \mu \mathrm{L}$ of rTaq (TAKARA, Japan), each of the forward and reverse primers $0.5 \mu \mathrm{L}$, and $17.0 \mu \mathrm{L}$ of nucleotide-free water (TAKARA, Japan). Thermocycler conditions used for PCR were $95^{\circ} \mathrm{C}$ for 5 min, followed by 30 cycles of denaturation at $94{ }^{\circ} \mathrm{C}$ for $30 \mathrm{~s}$, annealing at different temperatures listed in Table 2 for $40 \mathrm{~s}$, and extension at $72^{\circ} \mathrm{C}$ for $1 \mathrm{~min}$, with a final extension at $72{ }^{\circ} \mathrm{C}$ for $10 \mathrm{~min}$ before storage at $4{ }^{\circ} \mathrm{C}$. DNA from STEC O157:H7 strain EDL933 and nucleotide-free water were included as positive and blank controls, respectively. The PCR product was visualized using 1\% agarose gel electrophoresis under ultraviolet light.

In the next step, bacterial cultures positive to at least one of $s t x_{1}$ and $s t x_{2}$ were streak-plated onto sorbitol MacConkey agar (Hangzhou Microbial Reagent CO., LTD, Hangzhou, China), and incubated at $37^{\circ} \mathrm{C}$ for $18 \sim 24 \mathrm{~h}$. After this stage, the isolates were purified and cultured following the standard methods used for bacterial identification [73]. Presumptive isolates of E. coli were finally confirmed via Galanz staining, biochemical testing, and 16S rRNA amplification and sequencing.

\section{Serotyping and virulence genotyping}

O-polysaccharide antigens serogroups of STEC isolates were determined by Slide agglutination test based on the reaction of the bacterial strains against the 50 kinds of $\mathrm{O}$ antisera purchased from China Institute of Veterinary Drug Control (Beijing, China). STEC O157:H7 strain EDL933 was used as positive control.

Virulence genotyping was performed by PCR assays amplifying another three virulence associated genes eae, $e h x A$, and saa of with primers listed in Table 2. The PCR volume and procedure were the same as that used for determining the Stx encoding genes. Positive and blank control samples were included in each set of reactions. The PCR product was visualized using $1 \%$ agarose gel electrophoresis under ultraviolet light. The $s t x$ subtypes $\left(s t x_{1 \mathrm{a}}, s t x_{1 \mathrm{c}}, s t x_{1 \mathrm{~d}}, s t x_{2 \mathrm{a}}, s t x_{2 \mathrm{~b}}, s t x_{2 \mathrm{c}}, s t x_{2 \mathrm{~d}}\right.$, $\left.s t x_{2 \mathrm{e}}, s t x_{2 \mathrm{f}}, s t x_{2 \mathrm{~g}}\right)$ were also determined by PCR assays with primers and reaction procedures described previously [16].

\section{Cytotoxicity}

Vero cells (purchased from ATCC) were used to test the cytotoxicity of the STEC strains isolated herein. In brief, isolates were inoculated in Luria-Bertani (LB) broth (Sigma-Aldrich, MO) and shaken at $37{ }^{\circ} \mathrm{C}$ for $18 \sim 24 \mathrm{~h}$. Bacterial culture were then centrifuged at $20000 \times g$ for $40 \mathrm{~min}$, followed by a filtration through a $0.22 \mu \mathrm{m}$ membrane. Filtrate was inoculated into Vero cells and the cells were incubated at $37^{\circ} \mathrm{C}$ for $18 \sim 24 \mathrm{~h}$ to observe the morphology. Filtrates collected from STEC O157:H7 strain EDL933, E. coli DH5 $\alpha$, cell medium were included as controls.

\section{Antimicrobial susceptibility tests}

Antimicrobial susceptibility of the STEC isolates was determined by using the disc diffusion method, following the protocols recommended by Clinical and Laboratory Standards Institute [74]. A total of 14 types of antibiotics including amoxicillin (AMX), ampicillin (AMP), sulfafurazole (SIX), streptomycin (STM), norfloxacin (NRF), gentamicin (GEN), tetracycline (TET), neomycin (NEO), doxycycline (DOX), trimethoprim-sulfamethoxazole (SXT), kanamycin (KAN), cefotaxime (CFX), erythromycin (ERY), and ofloxacin (OFX) were tested. Results were interpreted using the CLSI breakpoints, when available. Resistance to colistin was also tested using broth microdilution method, as recommended by CLSI [74]. Colistin with final concentrations of $1 \mu \mathrm{g} / \mathrm{mL}, 2 \mu \mathrm{g} / \mathrm{mL}$, and $4 \mu \mathrm{g} / \mathrm{mL}$ was made in a $96-$ well plate in pre-reduced supplemented Mueller-Hinton (MH) broth (Hopebio, Qingdao, China). Interpretation of testing results was based on EUCAST breakpoint $(>2 \mu \mathrm{g} / \mathrm{mL}$ ), as the CLSI document (VET01S) does not provide a breakpoint for interpretation of colistin. Each antibiotic was tested with three duplicates. E. coli $\mathrm{ATCC}^{\mathrm{R}} 25922$ was used as quality control.

\section{Multilocus sequence typing}

Multilocus sequence typing (MLST) was performed using the previously described protocols [60]. Nucleotide sequences of seven housekeeping genes ( $a d k$, fumC, gyrB, icd, $m d h$, purA, and $r e c A$ ) were amplified and sequenced using the primers listed in Table 2. PCR reaction was performed in a $50-\mu$ l reaction mixture containing $2 \mu \mathrm{l}$ of the template DNA, $2 \mu \mathrm{L}$ of dNTP 
Table 2 Primers used in this study

\begin{tabular}{|c|c|c|c|c|c|}
\hline Primers & Sequences $\left(5^{\prime}-3^{\prime}\right)$ & Annealing Temp. $\left({ }^{\circ} \mathrm{C}\right)$ & $\begin{array}{l}\text { Product size } \\
\text { (bp) }\end{array}$ & Function & References \\
\hline \multicolumn{6}{|c|}{ Bacterial identification and virulence genotyping } \\
\hline$s t x_{1}-F$ & ACACTGGATGATCTCAGTGG & 60 & 614 & Amplifying stx 1 & Botteldoorn et al., $2003^{b}$ \\
\hline$s \mathrm{st}_{1}-\mathrm{R}$ & CTGAATCCCCCTCCATTATG & & & & \\
\hline$s t x_{2}-F$ & GGCACTGTCTGAAACTGCTCC & 64 & 255 & Amplifying stx2 & Leung et al., $2001^{d}$ \\
\hline$s t x_{2}-R$ & TCGCCAGTTATCTGACATTCTG & & & & \\
\hline $16 S-F$ & ATGGCTCAGATTGAACGC & 50 & 1505 & Amplifying 16 SrRNA & REN et al., $2012^{9}$ \\
\hline $16 S-R$ & CAGGTTCCCCTACGGTTA & & & & \\
\hline eae-F & GTGGCGAATACTGGCGAGACT & 64 & 890 & Amplifying eae & Nielsen et al., $2003^{e}$ \\
\hline eae- $R$ & CCCCATTCTITTCACCGTCG & & & & \\
\hline ehxA-F & GCATCATCAAGCGTACGTTCC & 60 & 534 & Amplifying $e h x A$ & Bandyopadhyay et al., $2011^{\mathrm{a}}$ \\
\hline ehxA-R & AATGAGCCAAGCTGGTTAAGCT & & & & \\
\hline saa-F & СCTCACATCTTCTGCAAATACC & 60 & 1688 & Amplifying saa & Paton et al., $2001^{f}$ \\
\hline saa- $R$ & GTTGTCGTTCATATITTACCATCCAATGGACATG & & & & \\
\hline \multicolumn{6}{|c|}{ MLST genotyping } \\
\hline Adk-F1 & TCATCATCTGCACTTTCCGC & 54 & 583 & Amplifying adk & Ding et al., $2012^{c}$ \\
\hline Adk-R1 & CCAGATCAGCGCGAACTTCA & & & & \\
\hline FumC-F1 & TCACAGGTCGCCAGCGCTTC & 54 & 806 & Amplifying fumC & \\
\hline FumC-R1 & GTACGCAGCGAAAAAGATTC & & & & \\
\hline GyrB-F1 & TCGGCGACACGGATGACGGC & 60 & 911 & Amplifying gyrB & \\
\hline GyrB-R1 & ATCAGGCCTTCACGCGCATC & & & & \\
\hline Icd-F1 & ATGGAAAGTAAAGTAGTTGTT CCGGCACA & 54 & 878 & Amplifying icd & \\
\hline $\mid c d-R 1$ & GGACGCAGCAGGATCTGTT & & & & \\
\hline Mdh-F1 & ATGAAAGTCGCAGTCCTCGGC GCTGCTGGCGG & 60 & 932 & Amplifying mdh & \\
\hline Mdh-R1 & TTAACGAACTCCTGCCCCAGAGCGATATCTTTCTT & & & & \\
\hline PurA-F1 & TCGGTAACGGTGTTGTGCTG & 54 & 816 & Amplifying purA & \\
\hline PurA-R1 & CATACGGTAAGCCACGCA GA & & & & \\
\hline RecA-F1 & CGCATTCGCTTTACCCTGACC & 58 & 780 & Amplifying recA & \\
\hline RecA-R1 & TCGTCGAAATCTACGGACCGGA & & & & \\
\hline Adk-F2 & TCATCATCTGCACTTTCCGC & - & - & adk Sequencing & \\
\hline Adk-R2 & CCAGATCAGCGCGAACTTCA & & & & \\
\hline FumC-F2 & TCACAGGTCGCCAGCGCTTC & - & - & fumC Sequencing & \\
\hline FumC-R2 & TCCCGGCAGATAAGCTGTGG & & & & \\
\hline GyrB-F2 & TCGGCGACACGGATGACGGC & - & - & gyrB Sequencing & \\
\hline GyrB-R2 & GTCCATGTAGGCGTTCAGGG & & & & \\
\hline Icd-F2 & ATGGAAAGTAAAGTAGTTGTTCCGGCACA & - & - & icd Sequencing & \\
\hline Icd-R2 & GGACGCAGCAGGATCTGTT & & & & \\
\hline Mdh-F2 & AGCGCGTTCTGTTCAAATGC & - & - & mdh Sequencing & \\
\hline Mdh-R2 & CAGGTTCAGAACTCTCTCTGT & & & & \\
\hline PurA-F2 & CGCGCTGATGAAAGAGATGA & - & - & purA Sequencing & \\
\hline
\end{tabular}


Table 2 Primers used in this study (Continued)

\begin{tabular}{cllll}
\hline Primers & Sequences $\left(5^{\prime}-3^{\prime}\right)$ & Annealing Temp. $\left({ }^{\circ} \mathrm{C}\right)$ & $\begin{array}{l}\text { Product size } \\
(\mathrm{bp})\end{array}$ & Function \\
\hline RecA-F2 & ACCTTTGTAGCTGTACCACG & - & - & References \\
RecA-R2 & TCGTCGAAATCTACGGACCGGA & & & \\
\hline
\end{tabular}

a Bandyopadhyay S, Mahanti A, Samanta I, Dutta TK, Ghosh MK, Bera AK, Bandyopadhyay S, Bhattacharya D. Virulence repertoire of Shiga toxin-producing Escherichia coli (STEC) and enterotoxigenic Escherichia coli (ETEC) from diarrhoeic lambs of Arunachal Pradesh, India. Trop Anim Health Prod. 2011;43(3):705-10 ${ }^{b}$ Botteldoorn N, Heyndrickx M, Rijpens N, Herman L. Detection and characterization of verotoxigenic Escherichia coli by a VTEC/EHEC multiplex PCR in porcine faeces and pig carcass swabs. Res Microbiol. 2003;154(2):97-104

'Ding Y, Tang X, Lu P, Wu B, Xu Z, Liu W, Zhang R, Bei W, Chen H, Tan C. Clonal analysis and virulent traits of pathogenic extraintestinal Escherichia coli isolates from swine in China. BMC Vet Res. 2012;8:140

dLeung PH, Yam WC, Ng WW, Peiris JS. The prevalence and characterization of verotoxin-producing Escherichia coli isolated from cattle and pigs in an abattoir in Hong Kong. Epidemiol Infect. 2001;126(2):173-9

' Nielsen EM, Andersen MT. Detection and characterization of verocytotoxin-producing Escherichia coli by automated 5' nuclease PCR assay. J Clin Microbiol. 2003;41(7):2884-93

fPaton AW, Srimanote P, Woodrow MC, Paton JC. Characterization of Saa, a novel autoagglutinating adhesin produced by locus of enterocyte effacement-negative Shiga-toxigenic Escherichia coli strains that are virulent for humans. Infect Immun. 2001;69(11):6999-7009

${ }^{9}$ REN L, YU X, SONG D, ZHEN K, QIN Y, WANG Y. Isolation, identification and phylogenetic analysis of E. coli from Yaks. China Animal Husbandry \& Veterinary Medicine. 2012;39(1): 168-171

mixture (TAKARA, Japan), $5 \mu \mathrm{L}$ of $10 \times \mathrm{PCR}$ buffer (TAKARA, Japan), $0.5 \mu \mathrm{L}$ of $\mathrm{rTaq}$ polymerase (TAKARA, Japan), each of the forward and reverse primer $1 \mu \mathrm{L}$, and $38.5 \mu \mathrm{L}$ of nuclease-free water. The reaction was performed under the following standard cycling procedure: an initial denaturation at $95^{\circ} \mathrm{C}$ for $5 \mathrm{~min}$, followed by 30 cycles of denaturation at $94^{\circ} \mathrm{C}$ for $30 \mathrm{~s}$, annealing at $54-60^{\circ} \mathrm{C}$ for $45 \mathrm{~s}$ (see Table 2), extension at $72{ }^{\circ} \mathrm{C}$ for $1 \mathrm{~min}$, and a final extension at $72^{\circ} \mathrm{C}$ for 10 min. The PCR products were initially analyzed by electrophoresis on a $1 \%$ agarose gel. Products with the correct size were sequenced at Sangon (Shanghai, China). Nucleotide sequences of the housekeeping genes were submitted to the Escherichia coli MLST Database (http://mlst.warwick.ac.uk/mlst $/ \mathrm{dbs} /$ Ecoli) to determine the sequence types automatically. Phylogenetic tree was generated based on the MLST data by MEGAX [26], using neighborjoining algorithm with 1000 bootstrapping.

\section{Abbreviations}

AMP: Ampicillin; CFX: Cefotaxime; DOX: Doxycycline; ERY: Erythromycin; GEN: Gentamicin; KAN: Kanamycin; LEE: The locus of enterocyte effacement; LPS: Lipopolysaccharide; MLST: Multilocus sequence typing; NEO: Neomycin; NRF: Norfloxacin; OFX: Ofloxacin; OMPs: Outer membrane proteins; Saa: STEC autoagglutinating adhesion; SIX: Sulfafurazole; ST: Sequence type; STEC: Shiga toxin-producing Escherichia coli; STM: Streptomycin; Stx: Shiga toxin; stx: Shiga toxin encoding genes; SXT: Trimethoprim-sulfamethoxazole; TET: Tetracycline

\section{Acknowledgements}

We acknowledge Dr. Shaowen Li at Huazhong Agricultural University College of Animal Science and Veterinary Medicine, Wuhan, China for kindly providing STEC O157:H7 reference strain EDL933.

\section{Authors' contributions}

$Z \mathrm{P}, \mathrm{XW}$, and BW contributed to the conception and design of this work; ZP, $W L, Z H, X L, R G, L H, X T$, and $C T$ participated in the sample collection, $P C R$ detection and bacterial isolation as well as the laboratory work with the bacterial isolates and the antimicrobial susceptibility testing; $\mathrm{ZP}, \mathrm{HC}, \mathrm{XW}$, and BW drafted and revised the manuscript. All authors read and approved the final manuscript.

\section{Funding}

This work was supported by the National Key Research and Development Program of China (Grant numbers: 2017YFC1600101 and 2017YFC1600103) from the Ministry of Science and Technology of the People's Republic of China, and the Agricultural Science and Technology Innovation Program of Hubei Province (Grant numbers: 2018skjcx05). Zhong Peng was supported in part by China Postdoctoral Science Foundation (grant number: 2018 M640719). The funders have no role in the study design, data collection and interpretation, or the decision to submit the work for publication.

\section{Availability of data and materials}

Not applicable.

\section{Ethics approval and consent to participate}

Not applicable. All of the clinical samples used in this study were submitted by veterinarians/or the farm owners to the Huazhong Agricultural University Veterinary Diagnostic Laboratory for routine testing.

\section{Consent for publication}

Not applicable.

\section{Competing interests}

The authors declare that they have no competing interests.

\section{Author details}

${ }^{1}$ State Key Laboratory of Agricultural Microbiology, College of Animal Science and Veterinary Medicine, Huazhong Agricultural University, Wuhan 430070, China. ${ }^{2}$ The Cooperative Innovation Center for Sustainable Pig Production, Huazhong Agricultural University, Wuhan 430070, China. ${ }^{3}$ Key Laboratory of Prevention and Control Agents for Animal Bacteriosis (Ministry of Agriculture), Animal Husbandry and Veterinary Institute, Hubei Academy of Agricultural Sciences, Wuhan, China.

Received: 22 July 2019 Accepted: 15 November 2019

Published online: 29 November 2019

\section{References}

1. Kaper JB, Nataro JP, Mobley HL. Pathogenic Escherichia coli. Nat Rev Microbiol. 2004;2:123-40

2. Mekata H, Iguchi A, Kawano K, Kirino Y, Kobayashi I, Misawa N. Identification of $\mathrm{O}$ serotypes, genotypes, and virulotypes of Shiga toxin-producing Escherichia coli isolates, including non-0157 from beef cattle in Japan. J Food Prot. 2014;77:1269-74.

3. Newell DG, La Ragione RM. Enterohaemorrhagic and other Shiga toxinproducing Escherichia coli (STEC): where are we now regarding diagnostics and control strategies? Transbound Emerg Dis. 2018;65(Suppl 1):49-71.

4. Croxen MA, Law RJ, Scholz R, Keeney KM, Wlodarska M, Finlay BB. Recent advances in understanding enteric pathogenic Escherichia coli. Clin Microbiol Rev. 2013;26:822-80. 
5. Fratamico PM, DebRoy C, Liu Y, Needleman DS, Baranzoni GM, Feng P. Advances in molecular serotyping and subtyping of Escherichia coli. Front Microbiol. 2016;7:644.

6. Bielaszewska M, Mellmann A, Zhang W, Kock R, Fruth A, Bauwens A, Peters $\mathrm{G}$, Karch $\mathrm{H}$. Characterisation of the Escherichia coli strain associated with an outbreak of haemolytic uraemic syndrome in Germany, 2011: a microbiological study. Lancet Infect Dis. 2011;11:671-6.

7. Corogeanu D, Willmes R, Wolke M, Plum G, Utermohlen O, Kronke M. Therapeutic concentrations of antibiotics inhibit Shiga toxin release from enterohemorrhagic E. coli O104:H4 from the 2011 German outbreak. BMC Microbiol. 2012;12:160.

8. Frank C, Werber D, Cramer JP, Askar M, Faber M, An der Heiden M, Bernard H, Fruth A, Prager R, Spode A, Wadl M, Zoufaly A, Jordan S, Kemper MJ, Follin P, Muller L, King LA, Rosner B, Buchholz U, Stark K, Krause G. Epidemic profile of Shiga-toxin-producing Escherichia coli O104:H4 outbreak in Germany. N Engl J Med. 2011;365:1771-80.

9. Wasey A, Salen P. Escherichia coli (E coli 0157 H7). In: StatPearls. Treasure Island: StatPearls Publishing StatPearls Publishing LLC; 2018.

10. Xiong $Y$, Wang $P$, Lan $R$, Ye C, Wang $H$, Ren J, Jing $H$, Wang $Y$, Zhou Z, Bai X, Cui Z, Luo X, Zhao A, Wang Y, Zhang S, Sun H, Wang L, Xu J. A novel Escherichia coli 0157:H7 clone causing a major hemolytic uremic syndrome outbreak in China. PLoS One. 2012;7:e36144.

11. Bai $X, H u$ B, Xu Y, Sun H, Zhao A, Ba P, Fu S, Fan R, Jin Y, Wang H, Guo Q, Xu X, Lu S, Xiong Y. Molecular and phylogenetic characterization of non0157 Shiga toxin-producing Escherichia coli strains in China. Front Cell Infect Microbiol. 2016;6:143.

12. Hu B, Kou ZQ, Shao CC, Yin HY, Liu ZD, Xu XH, Fang M, Chen BL, Wei CY, Li GF, Bi ZW. Characteristics and drug resistance of non-O157 Shiga toxinproducing E. coli in animal feces, from Shandong Province. Zhonghua Yu Fang Yi Xue Za Zhi. 2018;52:271-6.

13. Khan SB, Zou G, Xiao R, Cheng Y, Rehman ZU, Ali S, Memon AM, Fahad S, Ahmad I, Zhou R. Prevalence, quantification and isolation of pathogenic Shiga toxin Escherichia coli O157:H7 along the production and supply chain of pork around Hubei Province of China. Microb Pathog. 2018;115:93-9.

14. Shao CC, Hu B, Bi ZW, Kou ZQ, Fang M, Chen BL, Bi ZQ. Serotype identification and antibiotic susceptibility of Shiga toxin-producing Escherichia coli in the Weishan area in Shandong Province, China. Zhonghua Yu Fang Yi Xue Za Zhi. 2017;51:70-5.

15. Stevens MP, Frankel GM. The locus of enterocyte effacement and associated virulence factors of Enterohemorrhagic Escherichia coli. Microbiol Spectr. 2014;2:Ehec-0007-2013.

16. Scheutz F, Teel LD, Beutin L, Pierard D, Buvens G, Karch H, Mellmann A, Caprioli A, Tozzoli R, Morabito S, Strockbine NA, Melton-Celsa AR, Sanchez M, Persson S, O'Brien AD. Multicenter evaluation of a sequence-based protocol for subtyping Shiga toxins and standardizing Stx nomenclature. J Clin Microbiol. 2012;50:2951-63.

17. Brunder W, Schmidt H, Karch H. KatP, a novel catalase-peroxidase encoded by the large plasmid of enterohaemorrhagic Escherichia coli 0157:H7. Microbiology. 1996;142(Pt 11):3305-15.

18. Karch $\mathrm{H}$, Heesemann J, Laufs $\mathrm{R}$, O'Brien AD, Tacket CO, Levine MM. A plasmid of enterohemorrhagic Escherichia coli $0157: \mathrm{H} 7$ is required for expression of a new fimbrial antigen and for adhesion to epithelial cells. Infect Immun. 1987;55:455-61.

19. Paton AW, Woodrow MC, Doyle RM, Lanser JA, Paton JC. Molecular characterization of a Shiga toxigenic Escherichia coli 0113:H21 strain lacking eae responsible for a cluster of cases of hemolytic-uremic syndrome. J Clin Microbiol. 1999;37:3357-61.

20. Schmidt $H$, Beutin L, Karch H. Molecular analysis of the plasmid-encoded hemolysin of Escherichia coli O157:H7 strain EDL 933. Infect Immun. 1995; 63:1055-61.

21. Scotland SM, Willshaw GA, Smith HR, Rowe B. Properties of strains of Escherichia coli O26:H11 in relation to their enteropathogenic or enterohemorrhagic classification. J Infect Dis. 1990;162:1069-74.

22. Sherman P, Cockerill F 3rd, Soni R, Brunton J. Outer membranes are competitive inhibitors of Escherichia coli 0157:H7 adherence to epithelial cells. Infect Immun. 1991;59:890-9.

23. Heredia N, Garcia S. Animals as sources of food-borne pathogens: a review. Anim Nutr. 2018:4:250-5.

24. Hilborn ED, Mermin JH, Mshar PA, Hadler JL, Voetsch A, Wojtkunski C, Swartz M, Mshar R, Lambert-Fair MA, Farrar JA, Glynn MK, Slutsker L. A multistate outbreak of Escherichia coli O157:H7 infections associated with consumption of mesclun lettuce. Arch Intern Med. 1999:159:1758-64.

25. Olsen SJ, Miller G, Breuer T, Kennedy M, Higgins C, Walford J, McKee G, Fox K, Bibb W, Mead P. A waterborne outbreak of Escherichia coli 0157:H7 infections and hemolytic uremic syndrome: implications for rural water systems. Emerg Infect Dis. 2002;8:370-5.

26. Kumar S, Stecher G, Li M, Knyaz C, Tamura K. MEGA X: molecular evolutionary genetics analysis across computing platforms. Mol Biol Evol. 2018:35:1547-9.

27. Gonzalez Garcia EA. Animal health and foodborne pathogens: enterohaemorrhagic 0157:H7 strains and other pathogenic Escherichia coli virotypes (EPEC, ETEC, EIEC, EHEC). Pol J Vet Sci. 2002;5:103-15.

28. Heuvelink AE, van den Biggelaar FL, de Boer E, Herbes RG, Melchers WJ, Huis $\mathrm{JH}$, Monnens LA. Isolation and characterization of verocytotoxinproducing Escherichia coli 0157 strains from Dutch cattle and sheep. J Clin Microbiol. 1998;36:878-82.

29. Beutin L, Geier D, Steinruck H, Zimmermann S, Scheutz F. Prevalence and some properties of verotoxin (Shiga-like toxin)-producing Escherichia coli in seven different species of healthy domestic animals. J Clin Microbiol. 1993; 31:2483-8.

30. Beutin L, Miko A, Krause G, Pries K, Haby S, Steege K, Albrecht N. Identification of human-pathogenic strains of Shiga toxin-producing Escherichia coli from food by a combination of serotyping and molecular typing of Shiga toxin genes. Appl Environ Microbiol. 2007;73:4769-75.

31. Grant MA, Mogler MA, Harris DL. Comparison of enrichment procedures for Shiga toxin-producing Escherichia coli in wastes from commercial swine farms. J Food Prot. 2009;72:1982-6.

32. Houser BA, Donaldson SC, Padte R, Sawant AA, DebRoy C, Jayarao BM. Assessment of phenotypic and genotypic diversity of Escherichia coli shed by healthy lactating dairy cattle. Foodborne Pathog Dis. 2008;5:41-51.

33. Kaufmann M, Zweifel C, Blanco M, Blanco JE, Blanco J, Beutin L, Stephan R. Escherichia coli 0157 and non-0157 Shiga toxin-producing Escherichia coli in fecal samples of finished pigs at slaughter in Switzerland. J Food Prot. 2006;69:260-6.

34. Kobayashi H, Shimada J, Nakazawa M, Morozumi T, Pohjanvirta T, Pelkonen S, Yamamoto K. Prevalence and characteristics of Shiga toxin-producing Escherichia coli from healthy cattle in Japan. Appl Environ Microbiol. 2001; 67:484-9.

35. Lienemann T, Pitkanen T, Antikainen J, Molsa E, Miettinen I, Haukka K, Vaara M, Siitonen A. Shiga toxin-producing Escherichia coli O100:H(-): stx2e in drinking water contaminated by waste water in Finland. Curr Microbiol. 2011;62:1239-44.

36. Meng Q, Bai X, Zhao A, Lan R, Du H, Wang T, Shi C, Yuan X, Bai X, Ji S, Jin D, Yu B, Wang Y, Sun H, Liu K, Xu J, Xiong Y. Characterization of Shiga toxinproducing Escherichia coli isolated from healthy pigs in China. BMC Microbiol. 2014;14:5.

37. Sanchez S, Garcia-Sanchez A, Martinez R, Blanco J, Blanco JE, Blanco M, Dahbi G, Mora A, Hermoso de Mendoza J, Alonso JM, Rey J. Detection and characterisation of Shiga toxin-producing Escherichia coli other than Escherichia coli 0157:H7 in wild ruminants. Vet J. 2009;180:384-8.

38. Heiman KE, Mody RK, Johnson SD, Griffin PM, Gould LH. Escherichia coli O157 outbreaks in the United States, 2003-2012. Emerg Infect Dis. 2015;21: 1293-301.

39. Boerlin P, McEwen SA, Boerlin-Petzold F, Wilson JB, Johnson RP, Gyles CL. Associations between virulence factors of Shiga toxin-producing Escherichia coli and disease in humans. J Clin Microbiol. 1999;37:497-503.

40. Baranzoni GM, Fratamico PM, Gangiredla J, Patel I, Bagi LK, Delannoy S, Fach P, Boccia F, Anastasio A, Pepe T. Characterization of Shiga toxin subtypes and virulence genes in porcine Shiga toxin-producing Escherichia coli. Front Microbiol. 2016;7:574.

41. Cha W, Fratamico PM, Ruth LE, Bowman AS, Nolting JM, Manning SD, Funk JA. Prevalence and characteristics of Shiga toxin-producing Escherichia coli in finishing pigs: implications on public health. Int J Food Microbiol. 2018; 264:8-15.

42. Tseng M, Fratamico PM, Bagi L, Manzinger D, Funk JA. Shiga toxinproducing E. coli (STEC) in swine: prevalence over the finishing period and characteristics of the STEC isolates. Epidemiol Infect. 2015;143:505-14.

43. Scheutz F. Taxonomy meets public health: the case of Shiga toxinproducing Escherichia coli. Microbiol Spectr. 2014;2:1-15.

44. Orth D, Grif K, Khan AB, Naim A, Dierich MP, Wurzner R. The Shiga toxin genotype rather than the amount of Shiga toxin or the cytotoxicity of Shiga 
toxin in vitro correlates with the appearance of the hemolytic uremic syndrome. Diagn Microbiol Infect Dis. 2007;59:235-42.

45. Bielaszewska M, Friedrich AW, Aldick T, Schurk-Bulgrin R, Karch H. Shiga toxin activatable by intestinal mucus in Escherichia coli isolated from humans: predictor for a severe clinical outcome. Clin Infect Dis. 2006;43: 1160-7.

46. Friedrich AW, Bielaszewska M, Zhang WL, Pulz M, Kuczius T, Ammon A, Karch $\mathrm{H}$. Escherichia coli harboring Shiga toxin 2 gene variants: frequency and association with clinical symptoms. J Infect Dis. 2002;185:74-84.

47. Persson S, Olsen KE, Ethelberg S, Scheutz F. Subtyping method for Escherichia coli Shiga toxin (verocytotoxin) 2 variants and correlations to clinical manifestations. J Clin Microbiol. 2007;45:2020-4.

48. Aidar-Ugrinovich L, Blanco J, Blanco M, Blanco JE, Leomil L, Dahbi G, Mora A, Onuma DL, Silveira WD, Pestana de Castro AF. Serotypes, virulence genes, and intimin types of Shiga toxin-producing Escherichia coli (STEC) and enteropathogenic E. coli (EPEC) isolated from calves in Sao Paulo, Brazil. Int J Food Microbiol. 2007;115:297-306.

49. Beutin L, Montenegro MA, Orskov I, Orskov F, Prada J, Zimmermann S, Stephan R. Close association of verotoxin (Shiga-like toxin) production with enterohemolysin production in strains of Escherichia coli. J Clin Microbiol. 1989:27:2559-64.

50. Jajarmi M, Imani Fooladi AA, Badouei MA, Ahmadi A. Virulence genes, Shiga toxin subtypes, major O-serogroups, and phylogenetic background of Shiga toxin-producing Escherichia coli strains isolated from cattle in Iran. Microb Pathog. 2017;109:274-9.

51. Shin SW, Byun JW, Jung M, Shin MK, Yoo HS. Antimicrobial resistance, virulence genes and PFGE-profiling of Escherichia coli isolates from South Korean cattle farms. J Microbiol. 2014:52:785-93.

52. Cookson AL, Bennett J, Thomson-Carter F, Attwood GT. Molecular subtyping and genetic analysis of the enterohemolysin gene (ehxA) from Shiga toxinproducing escherichia coli and atypical enteropathogenic E. coli. Appl Environ Microbiol. 2007:73:6360-9.

53. Fratamico PM, Bhagwat AA, Injaian L, Fedorka-Cray PJ. Characterization of Shiga toxin-producing Escherichia coli strains isolated from swine feces. Foodborne Pathog Dis. 2008;5:827-38.

54. Uemura R, Sueyoshi M, Nagayoshi M, Nagatomo H. Antimicrobial susceptibilities of Shiga toxin-producing Escherichia coli isolates from pigs with edema disease in Japan. Microbiol Immunol. 2003:47:57-61.

55. Wang XM, Liao XP, Liu SG, Zhang WJ, Jiang HX, Zhang MJ, Zhu HQ, Sun $Y$, Sun J, Li AX, Liu YH. Serotypes, virulence genes, and antimicrobial susceptibility of Escherichia coli isolates from pigs. Foodborne Pathog Dis. 2011;8:687-92

56. Zhao S, White DG, Ge B, Ayers S, Friedman S, English L, Wagner D, Gaines S, Meng J. Identification and characterization of integron-mediated antibiotic resistance among Shiga toxin-producing Escherichia coli isolates. Appl Environ Microbiol. 2001;67:1558-64.

57. Cointe A, Birgy A, Mariani-Kurkdjian P, Liguori S, Courroux C, Blanco J, Delannoy S, Fach P, Loukiadis E, Bidet P, Bonacorsi S. Emerging multidrugresistant hybrid Pathotype Shiga toxin-producing Escherichia coli $\mathrm{O} 80$ and related strains of clonal complex 165, Europe. Emerg Infect Dis. 2018;24: 2262-9.

58. Denisuik AJ, Garbutt LA, Golden AR, Adam HJ, Baxter M, Nichol KA, LagaceWiens P, Walkty AJ, Karlowsky JA, Hoban DJ, Mulvey MR, Zhanel GG. Antimicrobial-resistant pathogens in Canadian ICUs: results of the CANWARD 2007 to 2016 study. J Antimicrob Chemother. 2018;74:645-53.

59. Zhang X, Zhang B, Guo Y, Wang J, Zhao P, Liu J, He K. Colistin resistance prevalence in Escherichia coli from domestic animals in intensive breeding farms of Jiangsu Province. Int J Food Microbiol. 2018;291:87-90.

60. Ding Y, Tang X, Lu P, Wu B, Xu Z, Liu W, Zhang R, Bei W, Chen H, Tan C. Clonal analysis and virulent traits of pathogenic extraintestinal Escherichia coli isolates from swine in China. BMC Vet Res. 2012:8:140.

61. Fierz L, Cernela N, Hauser E, Nuesch-Inderbinen M, Stephan R. Characteristics of Shigatoxin-producing Escherichia coli strains isolated during 2010-2014 from human infections in Switzerland. Front Microbiol. 2017:8:1471

62. Oprea M, Ciontea AS, Militaru M, Dinu S, Cristea D, Usein CR. Molecular typing of Escherichia coli $\mathrm{O} 157$ isolates from Romanian human cases. Jpn J Infect Dis. 2018;71:455-61.

63. Hauser $E$, Mellmann A, Semmler T, Stoeber $H$, Wieler LH, Karch $H$, Kuebler $N$, Fruth A, Harmsen D, Weniger T, Tietze E, Schmidt H. Phylogenetic and molecular analysis of food-borne Shiga toxin-producing Escherichia coli. Appl Environ Microbiol. 2013;79:2731-40.

64. Kang E, Hwang SY, Kwon KH, Kim KY, Kim JH, Park YH. Prevalence and characteristics of Shiga toxin-producing Escherichia coli (STEC) from cattle in Korea between 2010 and 2011. J Vet Sci. 2014;15:369-79.

65. Bielaszewska M, Mellmann A, Bletz S, Zhang W, Kock R, Kossow A, Prager R, Fruth A, Orth-Holler D, Marejkova M, Morabito S, Caprioli A, Pierard D, Smith G, Jenkins C, Curova K, Karch H. Enterohemorrhagic Escherichia coli O26: H11/H-: a new virulent clone emerges in Europe. Clin Infect Dis. 2013;56: 1373-81.

66. Chase-Topping ME, Rosser T, Allison LJ, Courcier E, Evans J, McKendrick IJ, Pearce MC, Handel I, Caprioli A, Karch H, Hanson MF, Pollock KG, Locking ME, Woolhouse ME, Matthews L, Low JC, Gally DL. Pathogenic potential to humans of bovine Escherichia coli O26, Scotland. Emerg Infect Dis. 2012;18: 439-48.

67. Januszkiewicz A, Wolkowicz T, Chrost A, Szych J. Characterization of the Shiga toxin-producing Escherichia coli $\mathrm{O} 26$ isolated from human in Poland between 1996 and 2014. Lett Appl Microbiol. 2015;60:605-8.

68. Marejkova M, Blahova K, Janda J, Fruth A, Petras P. Enterohemorrhagic Escherichia coli as causes of hemolytic uremic syndrome in the Czech Republic. PLoS One. 2013;8:e73927.

69. Zhang WL, Bielaszewska M, Liesegang A, Tschape H, Schmidt H, Bitzan M, Karch H. Molecular characteristics and epidemiological significance of Shiga toxin-producing Escherichia coli O26 strains. J Clin Microbiol. 2000;38:213440.

70. Zweifel C, Cernela N, Stephan R. Detection of the emerging Shiga toxinproducing Escherichia coli O26:H11/H- sequence type 29 (ST29) clone in human patients and healthy cattle in Switzerland. Appl Environ Microbiol. 2013;79:5411-3.

71. Stalb S, Barth SA, Sobotta K, Liebler-Tenorio E, Geue L, Menge C. Proinflammatory capacity of Escherichia coli O104:H4 outbreak strain during colonization of intestinal epithelial cells from human and cattle. Int J Med Microbiol. 2018;308:899-911.

72. Lee JB, Han D, Lee HT, Wi SM, Park JH, Jo JW, Cho YJ, Hahn TW, Lee S, Kang B, Kwak HS, Kim J, Yoon JW. Pathogenic and phylogenetic characteristics of non-0157 Shiga toxin-producing Escherichia coli isolates from retail meats in South Korea. J Vet Sci. 2018;19:251-9.

73. James V, Funke $G$, Jorgensen JH, Landry ML, Warnock DW. Manual of clinical microbiology. 10th ed. Washington DC: ASM press; 2011.

74. CLSI. Performance standards for antimicrobial disk and dilution susceptibility tests for bacteria isolated from animals, 3rd ed. CLSI suplement VETO1S. Clinical and Laboratory Standards Institute, Wayne 2015.

\section{Publisher's Note}

Springer Nature remains neutral with regard to jurisdictional claims in published maps and institutional affiliations.

\section{Ready to submit your research? Choose BMC and benefit from:}

- fast, convenient online submission

- thorough peer review by experienced researchers in your field

- rapid publication on acceptance

- support for research data, including large and complex data types

- gold Open Access which fosters wider collaboration and increased citations

- maximum visibility for your research: over $100 \mathrm{M}$ website views per year

At $\mathrm{BMC}$, research is always in progress.

Learn more biomedcentral.com/submissions 